Ankara Üniversitesi Türk İnkllâp Tarihi Enstitüsü Atatürk Yolu Dergisi

S 35-36, Mayı-Kasim 2005, s. 313-332

\title{
Ortadoğu Krizleri ve Türkiye
}

\author{
Yrd. Doç. Dr. Sabit DUMAN*
}

Özet

Bu çalışma Türkiye'nin Ortadoğu'da izlediği politikaya yeni bir bakış açısı ile ele almaktadır. 1948'de İsrail kurulduktan sonra Arap dünyasında Yahudilere karşı büyük bir tepki oluşurken aynı zamanda Arap ülkelerinde militan bir Arap milliyetçiliğinin doğmasına neden oldu. Yeni akımın temel özelliğ i anti batıcı olmastydı. Araplar Yahudiler karşısındaki yenilgilerini ellerinde olan demode silaha bağlarken aynı zamanda batılı devletlerin bu ülkeye yardım ettiğini de savundu. Türkiye, NATO'ya üye olarak güvenlik sorunlarını çözerken aynı zamanda batı ittifakının önemli bir üyesi oldu. Arap ülkelerinde batı düşmanlığı artarken Türkiye batının bir ortă̆ı olması Türklerle Arapların farklı politikalar izlemesine neden oldu. Türkiye soğuk savaşın önemli bir aktörü olarak Ortadoğu'da daha aktif bir politikaya yöneldi. Ancak gelişen olaylar Türkiye'nin beklediği gibi olmadr. Bağdat Paktına tek Arap devleti olarak Irak katıldı. Irak, batı desteğini alarak Arap dünyasının liderliğine soyunurken Misır buna karşı çıktı. Çekoslovakya ile silah anlaşması yapan Nasır, Pan Arap liderlinin en popüler ismi oldu. Süveyş'i millileştirmesi onu Arapların lideri konumuna yükseltti. Bu krizler sonrasında Sovyetler Birliği bölgeye girmesi tansiyonu artırdl. Türk-Suriye ilişkileri gerginleşti. Bütün bunların sonucunda Türkiye, Ortadoğu'dan uzaklaştı.

\section{The Middle East Crisis and Turkey}

\begin{abstract}
This article contributes another perspektive to Middle East from 1955 to 1958. After the Second World War ABD and USSR are born super powers. Strategic and millitary planning carried out since the end of the Second World War by the Western Allies for the contingency of a new world conflict aganist Soviet and his allies. The Middle East was vital strategic importance after beğining of the rival of two bloks. Clonel Nasser's announcement of the Czech arms deal in 1955, triggered the countdown to a new war in the region. Turkey is a partner of the Western block. He wanted to play a dominant role at establisment Baghdad Pact. After this Turkey
\end{abstract}

•İnönü Üniversitesi, Fen-Edebiyat Fakültesi, Tarih Bölümü 
has negative image in the Arab World. It is this historical burden that has so far prevented Turkey from playing more successfully the role of a mediator between Europe and the Middle East.

\section{Giriş}

Türkiye, Demokrat Parti dönemiyle birlikte daha kapsamlı bir dış politika izlemeye başladı. Öncelikle Türkiye, NATO'ya girdikten sonra Sovyetler Birliği'ne karşı daha aktif bir politika izlemeye başlarken komünizmin yayılmasını önlemek temel hedefi oldu. Bu nedenle Türkiye kendisinin de içinde bulunduğu çeşitli bölgesel paktların kurulmasında önemli görevler üstlendi. 1954 yılında Türkiye, Balkan Paktını Yugoslavya ve Yunanistan ile birlikte oluşturdu. Komünist bir yönetime sahip olan Yugoslavya bir anlamda Batı savunma sistemine dahil edilerek SovyetlerBirliği'nin Akdeniz'e inmesinin önüne geçilmek istendi. Bir NATO üyesi olan Türkiye, soğuk savaşın önemli bir aktörü gibi hareket ederek batı ittifakının bir parçası olduğunu gösterdi. Batı'da Balkan Paktı doğuda Türkiye-Pakistan anlaşması imza edildikten sonra Mısır'ın İngiltere ile anlaşmasından sonra Türkiye, Ortadoğu'nun savunmasını organize etmek için zamanın geldiğini düşündü' .

Türkiye, Ortadoğu'da da bir pakta kurmak için yoğun bir çaba göstermeye başladı. ABD, Soğuk savaş başladıktan sonra Sovyetlere karşı kuzey kuşağı oluşturmaya çalışırken bunun eksik halkası Ortadoğu idi. ABD Dışişleri Bakanı Dulles Ortadoğu'yu ziyaretinden sonra burada Sovyetler Birliğine karşı bir pakt oluşturmanın mümkün olmadığı gördü ${ }^{2}$. Ortadoğudaki Arap devletleri Sovyetlerden çok İsrail tehdidine önem verdiklerinden komünizm tehlikesi Araplar için bir şey ifade etmemekteydi. Irak daha ılımlı açıklamalar yaparak İngiltere ile anlaşma yapacağını söylerken Mısır ile de Arap güvenlik paktı konusunda anlaştıklarını açıkladı ${ }^{3}$ Araplar Ortadoğu'da İsrail'in kurulmasından Avrupalı güçleri sorumlu tuttukları için Arap kamuoyunda kuvvetli bir Batı aleyhtarlığı mevcuttu. Bu nedenle Batılı devletlerle her hangi bir ittifaka girmeleri dolaylı olarak İsrail'i tanımak olacaktı ki bu da mümkün değildi.

İngiltere, Süveyş’i elinde tutarak Akdeniz'deki gücünü korumak isterken Mısır buna karşı idi. Akdeniz savunması için İngiltere, Türkiye ve Mısır'ın da içinde olduğu bir savunma sistemi oluşturmaya çalışıyordu. İngiltere, Birinci Dünya Savaşı sonrasında Ortadoğu'da mandater bir devlet

${ }^{1}$ Forum Dergisi, C.II, S.21, 1 Şubat 1955, s.21; Dergi Başbakan Menderes'in Ortadoğu gezisini ve çabalarını başarılı olarak değerlendirmiştir.

2 A.B.D. Dıșişleri Bakanı John Foster Dulles, 12 -12 Mayıs 1953'te Kahire'yi, 14 Mayıs'ta Amman'ı, 15-16 Mayıs'ta Beyrut'u, 17-18 Mayıs'ta Bağdat'1, 18-19 Mayıs'ta Riyad'ı ziyaret etti. Türk hükümetinin daveti üzerine de 26 Mayıs 1953 'te Ankara'ya geldi. Foreign Relations of United States, 1952-1954, Part, I, Washington, D.C., 1986, ss. 168-190.

${ }^{3}$ Irak Dışişleri Bakanı Musa el Shabandar, Mısırlı gazetecilere verdiği demeçte Nasır’la Arap güvenlik paktı konusunda anlaş̧ıklarını bellirtti. The Times, 3 December 1954. 
olarak bulunması Arap ülkelerin büyük bir kısmın da ona karşı büyük bir antipati vardı. Diğer taraftan verdiği sözleri tutmaması da bu devlete olan güveni de azaltmıştı. Irak'ın İngiltere için özel bir anlamı vardı. İngiltere'nin burada deniz ve kara kuvvetleri olmadığı halde Kraliyet Hava Kuvvetleri bulunmaktayd ${ }_{1}^{4}$. Ayrıca İngiltere'nin burada başta petrol olmak üzere oldukça fazla ekonomik çıkarları da yatmaktaydı. İngiltere'nin buradaki ekonomik yatırımları oldukça fazla idi $^{5}$. Ayrıca Irak İngiltere'ye Türkiye'nin güney kanadını koruma gibi bir imkan sağlamaktaydı. 1948 yılında İsrail'in kurulması Arapları büyük bir hayal kırıklığına uğrattı. Arap topraklarında İsrail'in kurulmasını Araplar, batı devletlerinin yardımına bağladı. Bu da Arap dünyasındaki anti batıcılığı artırdı. Irak'ta batı eğitimi gören kesim anti-İngiliz duyguları taşırken 1953 yılında 65 yaşında olan Nuri Sait Paşa'nın sert yönetimine de karşıydılar. Irak'ta genelde diğer Ortadoğu ülkelerinde olduğu gibi muhalefet yoktu.

Türkiye'nin politikası Sovyetler Birliği'nin engelenmesi üzerine kurulmuştu. Bu nedenle İngiltere, Süveyş’ten çekildiği takdirde bunun yerini Sovyetler Birliği'nin doldurmasından çekinmekteydi ${ }^{6}$. İşin bir başka boyutu ise İngiltere'nin Mısır'dan çekilmesi Mısır'ın tam bağımsız bir devlet konumuna gelmesi Türkiye için bir önemi yoktu. İngiltere ile Misır bir anlaşma yaptığında Türkiye bundan memnunluk duydu? ${ }^{7}$. Kuzeyden Sovyet tehlikesini hisseden Türkiye, kendi güney kanadını emniyete almak niyetindeydi. Bunun da yolu Arap ülkeleriyele yakınlaşmaktan geçmekte idi. Bunun yanı sıra kurulacak bir pakta Arap ülkelerinin katılması da Türkiye'nin bölgedeki konumunu kuvvetlendirecekti. İngiltere'nin Irak'ta bulunması petrol sahalarını da kontrol etmesine imkan sağlıyordu ${ }^{8}$.

\section{Türkiye-Bağdat Paktı ve Arap Dünyası}

Türkiye, kurulacak pakta Arap devletlerinin katılması Arap ülkelerine Batı askeri ve ekonomik yardımın artmasına yol açacağı için bölgede

${ }^{4}$ NARS, Security Information US officials only Declassifed Intelligence Report, N0. 5980.2, 21 May 1953; E.O. 11332, sec.3(2) and 5(0), F 01 77-194; Burada yapilan yorumda İngiltere'nin Irak'ta giderek güç kaybettiğini ve Iraklıların her olumsuzluğu İngilizlere bağladığı belirtilmektedir.

5 ABD'ye verilen bir raporda İngiltere'nin Irak'taki konumunu ayrıntılı bir şekilde incelemiştir. Declassifed Intelligence Report 21 May 1953, No: 5980-2, Fo. 177-194.

6 Başbakan Menderes, Dulles ile görüşmesinde Süveyş konusuda gündeme gelirken Menderes, Kanal'ın yalnızca İngiltere ile Mısır arasında bir mesele olmadığını, stratejik konumu nedeniyle bütün hür dünyanın güvenliğini ilgilendirdiğini dolayısıyla Kanal'ın emin ellerde gerektiğini belirtti. Yukardaki Eser, ss.137-154.

719 Ekim 1954 de Misır ile İngiltere bir anlaşma imzalaması ve İngiltere'nin Misır topraklarından tamamen çekilmesini öngören bu anlaşmanın 4. maddesinde, Arap Birliği devletlerinden başka Türkiye'nin bir saldırıya uğraması halinde göz önünde tutulması Türkiye'yi oldukça memnun etti. Ayın Tarihi, Ekim 1954, s.29.

${ }^{8}$ NARS, Security Information US officials only N0. 5980.2, Declassifed Intelligence Report, 21 May 1953; E.O. 11332, sec.3(2) and 5(0), F 01 77-194. 
Arapların pakta karşı çıkmayacağı beklentisi içindeydi ${ }^{9}$. Türkiye, bölgede bir pakt kurmaya çalı̧ırken Arap dünyasında Pan-Arabizm akımı son derece etkiliydi. Bağdat Paktı kurulduğu anda Irak'ın Arap dünyasının lideri olacağı düşünülürken Süveyş krizinden sonra Arap dünyasının tartışmasız lideri Nasır oldu. Bağdat paktına karşı çıkması, Süveyş'te Mısır orduları yenilmesine rağmen bunu siyasi bir zafere dönüştüren Mısır başkanı Nasır, Arap dünyasının tartışmasız ve karizmatik lideri oldu. Kendisi ilk dönemlerde Arap lideri olma gibi bir düşüncesi yokken Ortadoğu'da gelişen olaylar onun Arap dünyasında bir lider olarak doğmasına neden oldu. Bağdat Paktından sonra Arap dünyasının liderliği için Irak kuvvetli bir konuma gelirken arkasından çıkan Süveyş krizi ile bu durumu Nasır lehine çevirdi. Irak Batıya yaklaşarak kendisini bölgenin en güçlü devleti olma planları yaparken daha sonraki olaylar buna izin vermedi ${ }^{10}$. Irak İngiltere desteğini arkasına alırken diğer yandan ABD'de Irak'a Bağdat Paktı çerçevesinde kullanilacak tank verecekti ${ }^{11}$.

Süveyş krizi sonrasında Arap dünyasında artan Anti batıcılıktan en fazla faydalanan lider Nasır oldu. Bu durum diğer Arap devletlerinde endişeye neden olarak bunun önüne geçmeye çalıştılar. Misır oluşan pakta son derece sert bir tepki göstererek bu durumun Arap Birliğini parçaladığını belirtti. Mısır'a göre Bağdat Paktı, uluslar arası ilişkilerde Mısır'ın Arap dünyasını ayrı bir güç haline getirme amacına ters düşmekteydi ${ }^{12}$. Irak Arap dünyasının liderliğine oynarken bu durum Nasır'ı oldukça tedirgin etti. Süveyş krizinden sonra Arap dünyasında Nasır'ın Arap dünyasında artan prestijini önlemek için 1957'de Suudi Arabistan, Ürdün ve Irak bir ittifak oluşturdu. Nasır ise 1958 yılında Suriye ile birleșerek bunu dengeleyerek bu birleşmeden sonra Arap dünyasının tartışmasız lideri konumuna yükseldi. Nasır'ın üçüncü dünyacılığı $1^{13}$, Batıya kafa tutması Arap dünyasında sempatiyle karşılanmaktaydı. Arap toprakları içinde İsrail'in kurulmasını Batı'ya bağlayan Araplar şimdi Batıya karşı mücadele eden onlardan korkmayan bir lidere sahip olmuşlardı.

Süveyş krizinden önce Bağdat Paktı Mısır ile Irak arasında temel sorunlardan biri olurken Nasır bunu kendi Arap liderliğine karşı bir meydan

${ }^{9}$ Ahmet Şükrü Esmer, Ulus gazetesindeki bir yazısında Türkiye'nin Bağdat Paktı çerçevesi içinde Arap ülkelerini toplayabileceğini umduğunu taşıyorken bunun gerçekleşmediğini belirtti. Ulus, 01.01.1956.

${ }^{10}$ Ingiltere, Irak'ın askeri kuvvetlerini eğitecek ve teknik yardım yapacaktı. The Times, 1.April 1955.

1 Irak'a verilecek tanklara Kongreden onay çıkmadan duyulmasını ABD istememektedir. Bu duyulduğu takdirde Araplarla İsrailliler arasındaki tansiyonun artacağına neden olacağı kaygısı vardır. Proposed reply from the President to Sir Antony Eden, E.O. 12066, sec. 1.301 (6), 1 January 1956.

${ }^{12}$ Keesing's Comtempary Archives 1955-1956, s.14057.

${ }^{13}$ Tito, Subat 1955 'te Nasır'ı ziyaret ederken hemen arkasından Nehru'da Nasır'ı n yanına gitti. Bandung'da 18-24 Nisan 1955 'te konferansa katıldı. Burada bağlantısızlar hareketinin de temeli atıldı. Nasır'da bu hareketin liderleri arasında yer aldı. İsrail, Bangdun konferansına kabul edilmedi. Zach Levey, "Israel's Entry Cyprus, 1959-1963,: Diplomacy and Strategy in the Eastern Mediterranean", Middle East Review of International Affairs, Vol.7, No.3, September 74 . 
okuma olarak algıladı. 24 Şubat 1955 'te Irak ile Türkiye bir askeri ittifak imzalayarak bu paktın temelini oluşturdu. Bu anlaşmaya diğer Arap ülkelerinin de katılması için çaba gösterme kararının alınması tepkilere neden oldu ${ }^{14}$. Daha sonra buna İran, Pakistan ve İngiltere'nin katılmasıyla Bağdat Paktı oluştu ${ }^{15}$. Irak'ın pakta girme nedeni batının ekonomik ve askeri yardımını alarak bölgedeki en güçlü Arap devleti olma konumuna yükseltmek isteği idi. Nasır, Irak'ın Arap dünyasında güçlü bir konuma gelmesine karşıydı. Irak'ın güçlenmesi Nasır'ın emellerine son derece aykırı olduğundan Mısır, hemen karşı atağa geçti. Nasır, bakanlardan birini 26 Şubat'ta Şam'a göndererek yeni bir Arap savunma sistemi için birleşik bir Arap gücü oluşturulmayı planladıklarını açıkladı. Ayrıca Irak yabancılarla ittifak yaptığı için buna dâhil edilmeyeceğini belirttiler. ${ }^{16}$

Bağdat Paktı ile Irak, güçlü bir konuma gelirken Suriye'yi de kendi yanına rahatça çekebilme imkânına sahip olabilrdi. Oysa Suriye'nin mevcut konumu Irak'ın yanında yer almasına imkân vermemekteydi. Suriye, Türkiye'den çekindiği için ve burada var olan Türk düşmanlığı nedeniyle Mısır'a daha yakın durmaktaydı. Diğer yandan Suudi Arabistan Haşimi Irak ile mücadele içinde olduğundan, Suriye Mısır'a daha sempatiyle bakmaktaydı. Mısır'a göre ise bu pakt Arap liderliğini Kahire'den Bağdat'a taşımakta ve Mısır'ı Arap dünyasında güçsüz bir konuma düşürmekteydi. Mısır, Arap dünyasındaki inisiyatifini kaybetmemek için Bağdat Paktı karşısına yeni bir blok oluşturmaya giriştiyse de Nasır'ın çabaları bir sonuç vermedi. Nasır, Bağdat paktı karşısında oluşturacağı pakt ile Bağdat Paktını etkisiz kılarak Irak'ı Arap dünyasında yalnız bırakarak kendisinin rakipsiz kalmayı amaçladı ${ }^{17}$. Bu nedenle Nasır, Suriye ve Suudi Arabistan ile Ekim ayında bir anlaşma imzalayarak bölgedeki güç dengesini kurmaya çalıştı.

Bağdat Paktının kurulması bazı devletleri farklı beklentilere itti ${ }^{18}$. Türkiye, komünizm tehlikesinin bölgeye girmesini engellemek isterken İngiltere, Ortadoğu'da tutunmak istemekteydi. İngiltere ve Irak, Ürdün'ü pakta çekmek için çok çaba gösterdi. Ürdün pakta katıldığı takdirde diğer Arap ülkelerinin de bu devleti takip edeceği tahmin edilmekteydi ${ }^{19}$. Ancak bu beklenti gerçekleşmedi. Ürdün bütün baskılara rağmen, Arap ülkelerinde aşırı milliyetçi eğilimden çekinerek pakta katılmak istemedi. Ürdün normal koşullarda pakta rahatça katılabilecek bir konumdaydı. Arap kamuoyunun baskısı sonucunda Ürdün ve Lübnan bekle gör politikası izlemekteydi.

${ }^{14}$ Keesing's Comteparary Archives, 1952-1954, s.13854.

15 1 Mart 1955 'te Celal Bayar, Pakistan'a gitti. Burada yaptiığı konuşmada iki ülkenin dünya barışı için birlikte çalışmaya hazır olduğunu belirtti. The Times, 1 Mart 1955.

${ }^{16}$ Elie Podeh, "The Drift Towards Neutrulity: Egyptian Foreign Policy During teh Early Nasserist Era", Middle Easteren Studies, Januarry 1996, Vol.32, No.1, s.169.

${ }^{17}$ The Times, 1 Februrary 1955.

${ }^{18}$ Pakistan, Hindistan ve Afganistan ile komşuydu ve her iki ülkeylede sınır problemleri vardı. Bu devletin Batıyla ilişkisi geliştiği takdirde ordusunu güçlendirip komşularına karşı daha etkili konuma gelebilecekti. Ara Sanjıan, "The Formulation of the Baghdad Pack", Middle Eastern Studies, Vol. 33, No. 2, April 1997, s.227.

${ }^{19}$ The Times'ta çıkan bir yoruma göre pakta kaşı çıkan yalnızca Suudi Arabistan'dı. The Times 4 February 1955. 
Ürdün'de yönetim batıya sempati duyarken halk buna karşıydı. Ülkede Bağdat Paktına karşı aşırı bir tepki de oluştu. Bu gösterileri Mısır basını da destekleyince Hüseyin, ülkesindeki bu tepkileri görünce Pakta girmekten vazgeçti. Suriye ise bu pakta karşıydı. Irak-Türkiye anlaşması imzalandığında Baas Partisi yanlıları sokaklarda Irak ve Türkiye aleyhinde gösteriler yapt ${ }^{20}$.

Diğer yandan Türkiye Bağdat Paktından beklentisi çok fazlaydd ${ }^{21}$. Bu pakt sayesinde batı yardımının daha çok gelmesini diğer taraftan da Sovyetleri buradan uzaklaştırmayı düşünmüştü. Mısır, Nasır liderliğinde ülkesini batıya bağımlı olmaktan kurtarmaya çalışırken, Menderes, bölgedeki Batı kaynaklı politikaları destekleyerek Batıyla olan bağlarını kuvvetlendirmeye çalışmaktayd ${ }^{22}$. İngiltere'nin Nisan ayında bu pakta katılmasına Sovyetler Birliği tepki gösterdi ${ }^{23}$. Ayrıca Türkiye, Arap ülkelerinin pakta karşı olumsuz tutum takınacaklarını da beklemiyordu. $\mathrm{Bu}$ nedenle Arap ülkelerini ikna etmek için Menderes Ürdün ve Lübnan'a gitti. Ancak burada protestolarla karşılaștı. İngiltere, Irak ve Türkiye'nin bütün gayretlerine rağmen pakta her hangi bir Arap devleti üye olmadı. Arap dünyasında Irak'ın etkinliğinin artması Suudi Arabistan'ı Misır'dan uzaklaştırırken Suriye, Türkiye ile Irak'ın yakınlaşmasından çekinerek Mısır'a yaklaştı. NATO üyesi olarak Türkiye bölgedeki en büyük askeri güçtï $^{24}$. Suriye'nin Türkiye ile mücadele etmesi beklenemezdi. Nasır, bütün çabasına rağmen Bağdat Paktına karşı en azından yanına bir Arap devletini yani Suriye'yi çekebildi. Bağdat Paktı kurulduktan sonra Nasır er fırsatta Irak'ı suçlamay başladı. Ayrıca Suriye ile bir pakt imzalayacakları konusunda anlaştıklarını ve bununla Suudi Arabistan'ın da ilgilendiğini belirtti ${ }^{25}$.

${ }^{20}$ The Times 1 March 1955; Bağdat Paktının kurulmasıyla Mısır'ın Arap dünyasında elde ettiği prestijin bir hamlede silinmesi idi. Forum Dergisi, C.3, S.25, 1 Nisan 1955, s.7.

${ }^{21}$ Fahir Armaoğlu, yaptığı değerlendirmede Bağdat Paktının beklenen sonuçlarının gerçekleşmediğini yazdı. Türkiye, Arap-İsrail meselesinde Arapları tutarak dış politikasında değişikliğe gittigini belirtmiştir. Fahir Armaoğlu, "1955 Yılında Milletlerarası Münasebetler", Forum Dergisi, C.4, S.43, 1 Ocak 1956, s.19.

${ }_{22}$ Türkiye'nin Bağdat paktına katılması bazı yazarlarca sert bir șekilde eleștirilerek Araplar tarafından Türkiye'nin Batı'nın bir oyuncağı şeklinde görüldüğünü öne sürdü. Oysa Bağdat Paktı bölgesel liderlikle doğrudan bağlantısı vardı. Bu açıdan bakıldığında Nasır'ın pakta karsı cephe alması ve Türkiye'yi de sert bir sekilde elestirmesi normal sayılmalı. Bu pakt olmasa da Türkiye'nin Demokrat Parti döneminde Batıyla ilişkileri son derece iyi bir düzeydedir. Bağdat paktına olumsuz yaklaşan bir makale için bkz. Mustafa Aydın, "Determinants of Turkish Policy: Changing Patterns and Conjunctures durin the Cold War", Middle Eastern Studies, Vol.36, No.1, january 200, p.114.

${ }_{23}$ Sovyetler Birliği yayınladığı bildiride bu duruma kayıtsız kalamayacağı ve burada yeni bir blokun olușturması bölgedeki devletlerin güvenliği olumsuz etkilediği gibi Sovyetlerin güvenliğini de tehdit ettiğini belirtti. Keesing's Comtemparary Archives, 1955$1956, \mathrm{~s} .14256$

${ }_{24} \mathrm{Bu}$ konuda $\mathrm{ABD}$ de Türkiye'ye bölgedeki en etkili ve büyük gücü olarak görmekteydi. Executive Office of the President, National Security Counsil, 5 December 1956, NSC 5510/1.

${ }^{25}$ The Times, 4 March 1955, Ayrica 14 Martta Suriye-Misır-Suudi Arabistan arasında bir pakt imzalanacağı yönünde haberler çıktı. The Times, 14 March 1955. 
Nasır, Bağdat Paktına karşı çıkarken Sovyetlerden aldığı silahlara güvendi. Ayrıca o Üçüncü Dünyacılığın önde gelen bir ismi olması nedeniyle Arap dünyasında önemli bir lider konumuna yükseldi. , Sovyetlerden silah almasıyla Ortadoğu'da Batının silah satıcılığı tekelini $\operatorname{kırdı}^{26}$. Arap dünyasında Batı karşıtlığı İsrail'e karşı odaklanmışken Nasır, 1956 Temmuzun da Süveyş Kanalını millileştirdi ${ }^{27}$. Bu Arap dünyasında Batı emperyalizmine karşı Arap milliyetçiliğin zaferi olarak yansıyınca Nasır, tartışmasız olarak Arap dünyasının lideri konumuna yükseldi. Arap ligi hemen toplanarak Mısır'ın Kanalı millileştirmesine destek verdi. Türkiye, Kanalın millileştirilmesine Bağdat paktının yarattığı atmosfer içinde baktı. Irak, bunu Nasır'ın devrilmesi için bir fırsat olduğunu düşündü. Irak Başbakanı Nuri Sait Paşa, İngiltere'nin bu oldubittiyi kabul etmeyerek duruma müdahale edeceğini düşünmekteydi. Ancak Irak bunu açıkça dile getirmekten çekinerek Mısır'ın bunu yapmasının kendisinin bir hakkı olduğunu belirtti. Ancak gerçekte bu durum Mısır'ı İngiltere ile karşı karşıya getireceği için memnun gözüküyordu. Resmi söylemde ise sorunun görüşmelerle çözülmesini savundu.

Mısır'ın Arap dünyasındaki yalnızlığını gidermek için Suriye, Mısır'a Arap ligi desteği sağlamaya çalışırken Nuri Sait Paşa ise Suriye'nin çabalarını boşa çıkartmak için gayret sarf etmekteydi. Irak'ın diplomatik çabalarından dolayı Suudi Arabistan, Libya, Sudan Mısır'a tam destek vermeden orta bir yol izlemeye başladılar. Suuudi Arabistan ile Irak arasında Birinci Dünya Savaşından sonra sürekli sınır tartışmaları oldu ve zaman zaman da silahlı çatışmalara da gidildi. Mısır'a destek veren Suriye'nin diğer devletleri kendi yanına çekme gayretleri neticesiz kalmasına rağmen Nasır, millileştirmeden vazgeçmedi. Kriz devam ederken Arap liderlerinin konuya barış̧̧ı bir çözüm bulma çabaları sonuç vermezken diğer taraftan batıya direnen Nasır'ın Arap kamuoyunda giderek yıldızı parliyordu. Nasır, Kıbrıs sorununda Yunanistan'a destek vererek adadan İngiltere'nin ayrılmasını istedi. İngilizler adadan ayrıldığı takdirde Süveyş'te tutunması mümkün olamayacaktı ${ }^{28}$. Nasır'ın bu tutumu Türkiye'nin Misır politikasını olumsuz etkiledi.

Soruna çözün bulmak için İngiltere 16 Ağustos 1956 yılında Londra'da 22 ülkenin katılımıyla bir konferans topladı. Bu konferansa Türkiye'de davet edildi $^{29} \cdot$ Bu konferansta soruna çözüm bulmak istenirken Arap dünyasında

${ }^{26}$ ABD, Molotov'a Mısır'a silah satışının Araplarla Yahudiler arasında bir savaş riski yaratacağını belirtti. Sovyetler ise 1948'den beri bu olasılığın giderek arttığını belirttiler. Ayrıca hem Sovyetlerin hem de Çekoslovakya'nın silah satış hakkının tartışmaya niyetli olmadıklarını da eklediler. Declassified MR 84-363-2, NLE, EO, 12343, Sec.1.3 (a) (3), 3 November 1955.

${ }_{27}^{27}$ Aslında Süveyş Kanalının millileştirmesini ilk ortaya atan Mısır Komünist Partisi idi. Bunu 1924 yılında belirterek anti-İngiliz bir politika ortaya koymuștu. Rami Ginat, "The Egyptian Left and the Roots of Neutralism in the pre-Nasserite Era", British journal of Middle Easteren Studies, 2003, Vol.30, No.1, s.7.

${ }^{28}$ Zeki Kuneralp, Sadece Diplomat, İstanbul, 1999, s.72.

${ }^{29}$ Türkiye'nin konferansa katılması Boğazlar açısından sakınca yaratabilirdi. Mısır, millileştirme hareketini meşru kılmak için Boğazlardaki Türk hakimiyetini örnek 
protesto gösterilerine neden oldu. Batıya karşı Arap tepkisi giderek büyümekteydi. Nasır bu toplantıya katılmayarak Batıya karşı meydan okumayı sürdürürken bunun özgürlüğe karşı emperyalizmin bir müdahalesi olarak belirtti. Bütün bunlar Arap dünyasında Nasır'a desteği artırken Arap devletlerinin liderleri buna pek fazla önem vermedi. Bu arada Suriye önderliğinde Mısır'a destek için Arap Suriye komitesi kuruldu. Bu farklı kesimlerden politikacılardan yazarlardan çeşitli kuruluşların temsilcilerinden oluştu. Böylelikle millileştirme yalnızca Mısır'ın bir iç meselesi olarak değil Batı emperyalizmine karşı mücadele şekline dönüştü. Bu komitenin girişimleriyle 18 Eylül'de Şam'da bir konferans düzenleyerek Mısır'a desteğini belirtirken bunun dişında her hangi bir şey yapmadı. Türkiye ise Ortadoğu'da meydana gelen krizden Sovyetlerin yararlandığını düşündü. Buradaki devletlerinde tarafız bir politika izlemelerini Sovyetlerin istediği bir tarz olduğu basında yapılan yorumlarda kendini belli etti ${ }^{30}$.

\section{Süveyş Krizi}

İsrail'in kurulmasından sonra Arap dünyasındaki en büyük kriz Süveyş'in millileştirmesi oldu ${ }^{31}$. Bu millileştirme Arap dünyasında Batı emperyalizmine karşı meydan okuyuş olarak algılanınca Batı ile yakın işbirliği içinde olan devletler için bir tehdit niteliğini aldı. Bu nedenle Irak, Nasır'a karşı daha sert bir tutum takınarak onu eleştirmeye başlarken Suudi Arabistan, Irak'ın bu tavrından rahatsızlık duydu. Arap dünyasındaki tepkileri gören Lübnan da Nasır'ın yanında yer almazken ona karşı da çıkmadı. Bu devletler Nasır'ın meydan okuması karşısında sessiz kalmayı yeğlerken, Nasır'ın Arap dünyasındaki imajının zarar görmesini istemekteydiler. Arap liderler kamuoyunun tepkisinden çekinerek Kasım ayında yaptıkları toplantıda açıklanan bildiride Mısır'ın yanında yer aldıklarını bildirmelerine rağmen el altından Nasır'ın devrilmesini istemekteydiler. Ayrıca ivme kazanan Arap milliyetçiliği kendi rejimleri için bir tehdit niteliğindeydi. Bu bakımdan Nasır, Arap liderlerinin desteğinden yoksun olmasına rağmen, Arap halkının büyük desteğini arkasında hissederken bu da kendisine büyük bir güç vermekteydi.

Arap devletleri Nasır tarafından öne sürülen tekliflere destek vermezken İngiliz tekliflerine sempati ile yaklaşmaktaydılar. Bağdat paktının bir üyesi olan Irak, İngiliz desteğini arkasına alarak Nasır'ın batının güçlü devletleri karşısında başarılı olamayacağını ve kanalı millileştiremeyeceğini

gösterebilirdi. Ayșegül Sever, Soğuk Savaș Kuşatmasında Türkiye, Batı ve Ortadoğu 1945 1958, İstanbul, Ekim 1997, s.160; Ayrıca Mısır'da bulunan Yunan azınlık Misır dıs politikasını da etkilemekteydi. Bu durum Yunanistan ile Mısır'ın yakınlaşmasına bir engel teskil ederken Kıbris konusunda Misır, Yunanistan'ın yanında yer almaktaydı. Amikam Nachmani, Israel, Turkey and Greece, Gainsborough house, Great Britain, 1987, s.103.

${ }^{30}$ Forum Dergisi, C.3, S.57, 1 Ağustos 1956.

31 1950'lerden sonra Araplarla iliskilerimizde belirleyici konu İsrail oldu. Arap devletleri bu ülkeyle ilişkilerimizi kesmemizi istedi. Bu durum uzun süre Türk-Arap ilişkilerine de damgasını vurdu. Zeki Kuneralp, Zoraki Diplomat, s.75. 
düşünmekteydi. Eğer İngiltere, Nasır'a karşı bir askeri harekât yaptığı takdirde Nasır' ın buna dayanması çok zordu. Mısır, İngiltere karısında fazla direnemeyeceği için savaş sonrası Nasır konumunu koruyamayacak ve Arap dünyasındaki prestijini kaybedecekti. Arap devletlerinin desteğinden yoksun olan Nasır'a Süveyş krizinde Arap kamuoyu büyük bir destek verdi ${ }^{32}$.

Nuri Sait Paşa'ya göre Nasır, İngiltere tarafından sunulan teklifleri kabul etmek zorundaydı. Nasır bunları kabul etse, batının isteklerine boyun eğdiği için Nasır zor durumda kalacaktı. Teklifleri red ederse bu kez o askeri harekat sonucunda prestij kaybedecekti. Bu nedenle Irak, Süveyş krizini Nasır'ın liderliğine vurulan bir darbe olarak bakmaktaydı. Irak'a göre Nasır son derece zor durumdaydı. Mısır'a karşı bir askeri harekât vuku bulduğu takdirde Nuri Sait Paşa Irak'ta sıkıyönetim ilan ederek pan-arabizmi önlemeye çalışacaktı. Diğer taraftan ise Irak Mısır'ın zayıflamasından doğan boşluğu doldurarak Arap liderliğine oynayabilecekti.

Nasır'a göre Nuri Sait Paşa, Batı'nın çıkarlarına göre hareket eden biriyken kendisi ülkesinin çıkarlarını birinci derecede savunan olarak görmekteydi ${ }^{33}$. Irak, bu dönemde bütün politikasını Nasır'ın Arap dünyasındaki gücünü azaltmaya yönelik bir politika izlemeye başladı. Mısır'ın gücü azalınca Ürdün, Irak'ın yanında rahatça yer alabilecek diğer taraftan Suudi Arabistan Misır'dan uzaklaşacaktı. Lübnan da Bağdat Paktına katılabilecek konuma gelebilecekti. Mısır'ın Sovyetlere yanaşması Suudi Arabistan'1 tedirgin etmekteydi. Ortadoğu'ya Sovyetlerin inmesine engel olmak için Suudi-Irak yakınlaşması başladı. Diğer taraftan Irak Başbakanı Nuri Sait Paşa, Birleşmiş Milletlere bir çağrı yaparak Filistin'li mültecilerin evlerine dönmelerini ve İsrail'in de kınanamasını isteyerek Arap kamuoyunun sempatisini kazanmaya çalışt ${ }^{34}$. Süveyş'in millileştirilmesi uluslar arası bir boyut kazandığı için Sovyetler Birliği de bu olaya seyirci kalmadı ve Mısır'ın yanında yer aldı. Suudi Arabistan, millileştirme konusunda Misır'a politik destek verirken Misır ile bir ittifak yapmaktan kaçındı. Suudi Arabistan Batı yardımına ihtiyaç duyuyordu. Diğer taraftan Arap dünyasında artan milliyetçilik bu devleti tam olarak Batı'nın yanında açıkça yer almaktan çekinmesine neden olmaktaydı. Nuri Sait Paşa, bu yakınlaşmayı sağlamak için Suudi Arabistan'a yaklaştı ve 1956 Eylülünde iki kral buluşarak Arap dünyasıyla ilgili konuları görüștü.. Bu görüşmede İbni Suud, Irak'ı batı yanlısı düşman kutupta olduğu için eleştirmeyeceğine, diktatör olarak nitelemeyeceğine dair söz verdi. Suudi Arabistan dış politika konusunda Irak'la uyum içinde olacaklarını belirterek bir bakıma Mısır'ın yanından uzaklaştığının açık belirtisiydi. Faysal'ın bu ziyaretine karşılık Suriye ve Mısır başbakanları hemen Riyad'a giderek Irak'ın etkisini azaltmak istediler. Böylelikle Suudi Arabistan ile Irak'ın yakınlaşmasını önlemeyi amaçladılarsa da bu konuda başarılı olamadılar.

${ }^{32}$ Roger Owen, State Power, and Politics in the Making of the Modern Middle East, London, 1992, 88.

${ }^{33}$ Miles Copeland, Devletler Oyunu, İstanbul, 1988, s.142.

${ }^{34}$ The Times, 14 November 1956. 
Süveyş kriz Irak ile Mısır'ın Arap dünyası üzerinde bir rekabete sürükledi. Mısır, Kore savaşında ABD ve Batı'nın görüşlerine karşı hareket ederek tarafsızlık politikasının da temellerini atmıștı. Daha sonra gelișen olaylar Mısır'ı bölgesel liderlik oynamaya iterken diğer yandan tarafsızlık akımının da öncü bir devleti yaptı ${ }^{35}$. Irak, Batıya daha yakın olan Ürdün'ü kendi safına çekmek isterken bu devlet Bağdat Paktına girmeyerek tarafsız konumunu korumaya çalıştı. Ürdün bir bakıma gelişmelere göre politika geliştirme niyetindeydi. Ürdün'ün tamamen Mısır'a angeje olamazdı çünkü Batı'nın ekonomik yardımına ihtiyacı vardı. Batı yardımı Irak'a akmaktaydı. Süveyş krizi Ürdün'ü Irak'a yaklaştırdı. Savaş tehlikesi baş gösterince Ürdün İsrail'in kendisine saldırmasından korkarak Irak'tan askeri yardım talep etti. Irak bu teklife olumlu yanıt verdi. Ayrıca Irak'ın Ürdün'e asker göndermesi Hüseyin'in Mısır'dan uzaklaşması demekti. İsrail'de bunu Misır'ın bölgedeki üstünlüğüne son veren bir hareket olarak değerlendirirken kendisi de bir Irak-İsrail savaşının çıkma ihtimalini göz ardı etmedi3i ${ }^{36}$. Nasır'da bu durumu görerek Irak'ın Ürdün'e asker göndermesini İsrail tehdidi nedeniyle değil Mısır'ı Ürdün'den uzaklaştırmak amacını taşıdığını belirtti. Ancak daha sonra Ürdün'e gönderilen Iraklı kuvvetlere kimin komuta etmesi konusunda sorun çıkınca görüşmeler kesildi. Bunun üzerine Ürdün, asker istemekten vazgeçti. Irak, kendi askerlerinin ülke içerisinde Ürdün sınırına yakın bir yere yerleştirilmesini kabul ederek Ürdün'ün bir saldırıya uğradığı takdirde veya Ürdün'ün talep etmesi halinde harekete geçeceklerdi.

Süveyş kanalı askeri açıdan Batı için son derece önemli stratejik bir konuma sahipti. Dolayısıyla Nasır, Süveyş kanalını millileştirerek Batı emperyalizmine karşı bir meydan okumaktaydı. Bu durumda İngiltere bunu kabul etse Nasır'a karşı boyun eğmiş olacak ve Nasır daha güçlenecekti. İngiltere bunu kabul etmeyerek Nasır'a karşı bir askeri harekât planlayarak Kanal'a müdahale kaçınılmaz gözükmekteydi. İsrail 26 Ekim 1956'da Mısır'a karşı saldırıya geçerken İngiltere ve Fransa Misır'a bir nota vererek her iki tarafın kanaldan 10 mil geri çekilmesini istediler. Kanalı korumak içinde stratejik mevkileri işgale başladılar. Bu saldırı Türkiye tarafından kınand ${ }^{37}$.Aynı zamanda da ABD, Sovyetler Birliği ile birlikte hareket ederek müttefiki olan İngiltere'nin bu saldırısına destek vermedi. Bunun arkasından İsrail Sina yarımadasını işgal edince, Suriye, Suudi Arabistan, Ürdün Mısır'a askeri destek vereceklerini belirtmelerine rağmen Nasır, Mısır kuvvetlerini Sina'dan çekti. Nasır, bu durumun Batılı emperyalist devletlerin Suriye'yi işgal için bir bahane olacağını düşündü. Nasır, Batı karşısında Sovyet

${ }^{35}$ Mısır uzun süre bir yabancı egemenliği altında kalmıştı. Bu nedenle bağımsızlığını sınırlandıran her şeye karşıydı. İngiltere'nin Mısır'da bulunması Batı'ya karşı duyguları da tahrik etmekteydi. Bu nedenle ilk firsatta Batı ile bağlarını kesmek Mısır için hayati bir önem taşımaktaydı. Mısır'ın tarafsızlık politikasına yönelişini analiz eden Rami Gimat'ta Mısır'ın bu politikaya Waft Partisi döneminde başladığını ileri sürmektedir. Rami Ginat, "The Egyptian Left and the Roots of Neutralism in the pre-Nasserite Era", s.5.

${ }^{36}$ The Times 15 October 1956

${ }^{37}$ Ayın Tarihi, Kasım 1956, No..276, s.41. 
desteğini almak için Mısır başbakanı Moskova'ya gitti. Diğer yandan İngiliz hava kuvvetleri Mısır propaganda merkezini yıkarken bunun yerine Şam radyosu aldı. Bu arada Suriye, Suudi Arabistan, Irak birlikleri Ürdün'ün daveti üzerine bu ülkeye girdi. Diğer taraftan Suriye, Suudi Arabistan İngiltere ve Suudi Arabistan ile diplomatik ilişkilerini kesti.

Mısır'ın saldırıya uğraması Arap dünyasında yoğun bir tepkiye neden olurken Irak en fazla tepki toplayan devlet oldu. ABD de saldırıyı kınayarak bir bakıma Sovyetlerle aynı tavrı sergiledi. Savaşın başından beri devam eden gösteriler anti Batıcı bir merkeze otururken Bağdat Paktına üye olan Irak'ın Arap davasına ihanet ettiği sık sık gündeme gelmekteydi. Ayrıca Nuri Sait Paşa da gösterilerin baş hedefi haline geldi. Misır ve diğer Arap ülkelerinde batı karşıtı milliyetçi gösteriler yapıld ${ }^{38}$. Ürdün'de yeni kurulan kabine halkın bu talebini Irak'a ilettiyse de bir sonuç alınamadı. Diğer taraftan Suriye'de Kerkük-Tropoli petrol boru hattına sabotaj yapıldı ${ }^{39}$. Bu zarar İngiltere'nin baskısıyla Irak'a ödetilirken petrol gelirlerinden mahrum kalan Irak bütçesi de zora girdi. Bu sabotajı planlayan Şam'daki Mısır konsolosluğuydu. Arap dünyası bir kaosun içine sürüklendiği için herkes bireysel eylemciydi. Ayrıca boru hattının bombalanması taktik bir hataydı. Uzun süre kullanılmayan Kerkük-Hayfa boru hattı tekrar ișletilebilirdi. Sabotajların artması Suriye içinde iyi olmayabilirdi ve Bağdat paktı ile karşı karşıya kalabilirdi.

Savaş başladıktan sonra Lübnan başkanı bütün Arap liderlerini bir toplantıya çă̆ırarak konuya ilgisiz kalmadığını göstermek istedi. Konferans 13 Kasımda toplanırken Nasır buna katılmadı. Yerine Beyrut'taki Mısır büyükelçisi katıldı. Buradaki temel konu Arapların İngiliz ve Fransızlarla olan diplomatik münasebetleri idi. Suriye Başkanı Kuvvetli, bütün Arap devletlerinin Mısır, Suriye ve Suudi Arabistan'ı takip etmeleri gerektiğini söyledi. Faysal, İngilizlerle ilişkilerin kesilmesine karşı çıkarken Fransa ile ilişkilerin kesilmesinden yanaydı. Lübnan, Libya ve Sudan, Irak'ın 1lımlı politikasını destekledi. Mısır, Suriye'nin aşırı Batı düşmanlığı konusunda hem fikir değildi. Konferans 1 lımlı bir havada devam etti ve Mısır'ın politikasına destek verildi. Suriye'deki fanatizme rağmen Lübnan başkanı havayı sakinleştirmeyi başardı. Irak'ta ise Nuri Sait Paşa içte kontrolü sağlamak için büyük çaba gösterirken İngilizlerden de bir hafta içinde ateşkes ilan etmelerini ve İsrail'in geri çekilmesini istedi ${ }^{40}$. Bu durum İngilizleri memnun etmedi. ABD'nin ateșkes önerisini destekleyen Türkiye Birleşmiş Milletlerde de bu yönde oy kullandı. Bunun sonucunda önerge Birleşmiş Milletler de 4'e karş1 64 oyla kabul edilmesi üzerine İngiltere 6 Kasım 1956'da ateşkes ilan etti.

${ }^{38}$ Forum Dergisi, C.6, S.64, 15 Kasım 1956.

${ }^{39}$ The Times, 4 April 1955.

40 Başbakan Menderes, İngiltere'nin pakta kalması için tarafları ikna etmeye muvaffak oldu. Bağdat paktı üzerindeki baskıların azalması için de ABD'nin Pakta davet edilmesi istenmekteydi. Foreign relations of United States, 1955-1957, Vol. XII, ss.318-319. 
Süveyş krizinin bir sonucu olarak, İngiltere'nin müttefikleri Arap dünyasında oldukça zor durumda kaldı. İngiltere'nin başarısızlığ 1 Türkiye'nin konumunu sarstığı gibi diğer batı yanlısı ülkeleri de olumsuz etkiledi ${ }^{41}$. Arap dünyasında İngiliz yanlısı devletler prestij kaybına uğrarken Nasır'ın prestij kazanmasına da engel olamadı. Bu nedenle Türkiye ve Batı yanlısı Arap devletleri Mısır'ın etkisini azaltmaya yönelik bir politika izlemeye başladılar. Araplar yalnızca batı güçleri tarafından değil, aynı zamanda İsrail'in saldırısına da uğramıştı. Süveyş'e askeri müdahale yapılması üzerine 5-8 Kasım tarihleri arasında Tahran'da yapılan Bağdat paktı toplantısına İngiltere davet edilmedi. Bu toplantı sonunda yayınlanan bildiride İsrail saldırısı kınanırken İngiltere ve Fransa'ya değinilmemekteydi ${ }^{42}$. Bildiride ayrıca İngiliz ve Fransız güçlerinin Mısır topraklarından çekilmesini ve Misırlı rehinelerin serbest bırakılmasını talep edildi. Irak ise Bağdat Paktının bir üyesi Batı ile müttefik konumundaydı. Bu nedenle Irak zor durumdaydı. Böyle olunca Iraklı liderler Arap dünyasının hedefi haline geldiler. Nuri Sait Paşa ve Irak Kralı, İngiltere ile İsrail'in Mısır'a saldırmasından çok kötü bir şekilde etkilendi. Artan tepkiler nedeniyle içerdeki durumu yatıştırmak için hükümet sıkıyönetim ilan etmek zorunda kald ${ }^{43}$. Bu gerginlik sürerken bir Irak üst düzey yetkilisi ise Türkiye ve Irak'ın Suriye'ye saldıracağını söyledi ${ }^{44}$.

Olaylar bu yönde gelişirken bütün Arap dünyasında tepkiler büyüktü ve dinmek de bilmiyordu. Ürdün Kralı Hüseyin, Irak'tan asker talep ettiğinde gönderip göndermeme konusunda Nuri Sait Paşa tereddüt etti. Öncelikle kumanda sorunu vardı ve iki ülke bu konuda anlaşmazlık içindeydi. Nuri bir Arap tehdidinden korkarken Hüseyin için öncelikli tehdit İsrail idi. Sonunda Irak, Ürdün'ün teklifini kabul ederek Ürdün komutası altında bu ülkeye asker gönderdi. Diğer yandan Nuri Sait Paşa İngiltere'ye güvence vererek İsrail, Ürdün'e saldırmadıkça Irak'ın İsrail'le savaşmayacağını söyledi. Bunun bir belirtisi olarak Iraklı askerler İsrail sınırından uzak bir bölgeye yerleştirildi. Diğer taraftan ABD, Mısır'ın bozulan ekonomisine dikkat çekerek huzursuzluğun arttığını resmi raporlarında belirtti ${ }^{45}$.

Arap milliyetçiliği giderek sertleşirken Irak sert bir şekilde eleştirilmekteydi. Bu eleştirilere rağmen Nuri Sait Paşa, Bağdat paktından çekilme taleplerini reddetti. Ona göre bu pakt, Arap dünyasında Irak'ın konumunu yükseltmek için bir araçtı. 2 Kasım'da Tahran'a giderek paktın Müslüman üyeleri ile görüştü. Nuri Sait Paşa, 9 Kasım 1956'da Bağdat Paktı toplantılarının üç Müslüman devletle sınırlı kalmasını gerektiğini belirten bir hükümet kararını kamuoyuna açıkladı. Bunun üzerine paktın

${ }^{41}$ Ayşegül Sever, Soğuk Savaş Kuşatmasında Türkiye, Batı ve Ortadoğu 1945-1958, İstanbul, Ekim 1997, s. 165-166.

${ }_{42}$ Keesing Comtemparary Arhives, 1955-1956, s.15230.

${ }^{43}$ The Times, 2 November 1956.

${ }_{44}^{4}$ Intelligence notes, secret E.O. $12356 \mathrm{ssec} .3 .4$ (6), F ) 1-405.

${ }^{45}$ NARA, 3 December 1956; secret, EO. Sec. 3.4. (b), NSC, F.91-405, MR. 90-428; Sovyetlerin bölgeye girmemesi için ABD'nin ekonomik yardım yapması öngörüldü. 
diğer üyeleri Bağdat'a giderek Irak'ın pakta kalması için çaba gösterdiler ve bunda da başarılı oldular. Nuri'nin bu gidişi ülkede tansiyonu düşüreceği yerde konferans sonunda alınan kararlar tepkileri daha da artırdı. Tahran'da Nuri Sait Paşa, savaşı sona erdirmek için aktif bir role soyunarak Filistin konusunda da inisiyatifi eline almak istedi. Nuri Sait Paşa, Irak'a dört öneri ile döndü. Hükümetin onayını alarak bunları kamuoyuna açıkladı. Mısır'ın bağımsızlığı ve toprak bütünlügü korunacak, İsrail, mütareke öncesi sınırlara çekilecek, savaş esirleri serbest bırakılacak ve Filistin konusunda bir çözüme varılacak. Burada Nuri iki amaç peşindeydi. Birincisi Bağdat paktını savaşı sona erdirmesi konusunda kritik bir rol oynayacak pozisyona getirmek diğer yandan kamuoyunun dikkatlerini Filistin'e yönlendirmekti. Irak bu konuda önemli bir rol oynayacaktı. Konferans 8 Kasım'da açılırken mütareke çoktan ilan edilmişti. Konferans sonunda okunan bildiride İngiltere'nin mütareke ilan etmesinde paktın Müslüman üyelerinin etkili olduğu vurgulanmıştı. Diğer yandan 13 Kasımda Irak, Filistin konusunda radikal kararlar almaya gitti. İsrail'e bir çağrı yaparak mültecilerin evlerine geri dönüşüne izin vermesini istedi. Bu Irak'ın İsrail'e karşı tutumunu sertleştirmesi demekti. Böylelikle Arap-İsrail çatışmasında temel olan taksim planına yaklaşması demekti. Bu aşırı milliyetçi Arap politikasına dönüş Irak için son derece önemliydi. Burada Filistin konusu bir kez daha Arap dünyasında liderlik konumuna yükselme mücadelesinin odak noktasına dönüştürüldü ${ }^{46}$.

Kriz bitince 17 Kasımda paktın Müslüman üyeleri paktın geleceği görüşülerek İngiltere'nin pakta kalması kabul edildi. İngiltere'nin savaşa katılıp Arapların büyük tepkisini çekmesine rağmen pakta kalması ilginçti. Diğer yandan ABD'nin pakta katılması için davet yapılması kararlaştırıldı ${ }^{47}$. Ancak ABD, bölgeye daha fazla karışmak istemedi. Bunu yapmadan önce Nuri Sait Paşa, konferansta Irak'ın çıkarlarını ön plana getirmeyi ümit etmesine rağmen zamanlamayı iyi yapamadı. Ülkede Misır'ın etkisiyle büyük öğrenci gösterilerine sahne olurken buna ek olarak Suriye, ülkesinde Irak'ın bir darbe planladığını öne sürdü. Bu söylenti iyi planlanmış etkisi de oldukça büyük oldu ${ }^{48}$. Temelde Irak'ın Arap dünyasındaki konumunu sarsmaya yönelikti. Darbe, 25 Ekim'de İngiltere'nin Fransa'nın İsrail'in Süveyş'e saldırdığı zaman planlandığını açıkladıklarında Irak Arap dünyasında oldukça zor durumda kaldı.

\section{Nasır, Arap dünyasının Lideri}

Süveyş krizi olduğu sırada Macaristan'daki milliyetçi ayaklanmayı Sovyetler sert bir şekilde bastırdı. Sovyetler Macar ayaklanmasını bastırırken

${ }^{46}$ Irak'ın endişelerini ortadan kaldırmak, Irak'ın kamuoyundaki itibarını artırmak için Türkiye, İsrail'le ilişkilerinin gözden geçirmesi bir bakıma Irak'ın Arap dünyasındakini prestijini artırmaya yönelik çabalardı. Menderes hükümeti bu nedenle İsrail'le ilișkilerini tam olarak kesmese de Tel Aviv'deki Büyükelçisini geri çekti. TBMM Tutanak Dergisi, 1954-1957, Dönem X, 28.12.1956, s.331.

${ }^{47}$ Foreign Relations of United States 1955-1957, vol. XII, s.338.

${ }^{48}$ Irak'a yönelik radyo yayınları artınca ABD buna karşılık verme gereğini hissetti. Intelligence Notes, 3 December 1956, Sec. 3 (4) NSC, F91-405; MR, 90-428. 
Mısır'a İsrail'in saldırması üzerine İngiltere ve Fransa'nın katılması Türkiye'yi zor durumda bıraktı ${ }^{49}$. Kriz nedeniyle de İngiltere ve Fransa'y1 füzelerle tehdit etmekten çekinmeyen Sovyetlerin imajı Arap dünyasında oldukça $\operatorname{artt}^{50}$. Irak bütünüyle Arap dünyasından izole edildiğinde Mısır, Bağdat paktına karşı açıkça daha sert bir tutum aldı. Paktın islami bir yapıya dönüşmesi Mısır için yeni bir tehditti. Bu durumda diğer Arap ülkelerinin pakta katılması daha kolay olabilirdi. Pakt gücünden çok şey kaybetse de paktın yeni çehresi Arap ülkelerini Mısır aleyhine dönüştürme ihtimal Nasır'ı oldukça rahatsız etmekteydi. Bu politika Mısır-Suudi yakınlaşmasını önlemeye yönelikti. Paktın diğer üyeleri Pakistan başkanını Riyat ve Beyrut'a göndererek komünizme karşı işbirliğini artırarak bunun islami bir pakt oluşturmak için işbirliği imkânı araştırıldıysa da Suudi Arabistan buna yanaşmadi.

Süveyş krizinden yararlanan Şam ve Kahire radyoları Irak yönetimini eleştirirken, Sovyetlerde Türk askerinin Irak'a gönderildiğini duyurdu. Bu Ankara tarafindan ret edildi ${ }^{51}$. Misır, Suriye ve Sovyetlerin amacı Irak yönetimini tamamen köşeye sıkıştırmaktı. Irak, Arap dünyasında desteksiz kalınca Nuri Sait Paşa, Mısır'a yaklaşmaya çalışarak Tevfik el Suwaidi'yi Nasır'a göndererek ikili bir zirve talep etti. Nuri Sait Paşa, bunu yaparken iki ülke arasındaki uzun süren düşmanlığın sona ermesi ve Nasır'ın komünizme karş1 işbirliği yapabileceğini ve Filistin probleminin çözümü için destek vereceğini ummaktaydı. Nasır, bu öneriyi ret edince Irak'ın Arap dünyasındaki yalnızlığı da sürdü Diğer yandan Nasır, Arap liderliğine oynarken aynı zamanda Afrika'da da etkili olmaya çalışmaktaydı ${ }^{52}$. Nuri Sait Paşa bu öneriyi yaparken Mısır'ın içinde bulunduğu ekonomik koşullar Irak'la zorunlu işbirliğine gideceğini düşünmüştü. Ancak Mısır o dönemde Sovyetlerle iyi ilişki kurduğundan Irak'ın planları sonuçsuz kaldı.

Batı dünyasına göre Nasır'ın amacı Arap dünyasında bir diktatör olmaktı. Bunu da gerçekleştirmenin yolu kendisine rakip olarak gördüğü Irak rejimini devirmekten geçmekteydi. Irak, Batıyla yakın ilişkide İngiliz desteğine sahip bir ülkeydi. Irak, Batı yanlısı bir tutum alarak Arapların tepkisini aldı ve böylelikle Arap dünyasından izole oldu. Irak'ın arayışları da bu yalnızlıktan kurtulmak içindi. İngilizler Irak'ı destekleyerek Arap dünyasındaki gücünü artırmak istiyordu. İngilizler, Nuri Sait Paşa'nın yeteneklerine fazla güvendiklerinden Arap dünyasındaki gelişmeleri değerlendirmekten uzak olduğu için bölge hakkında sık sık yanılgılara düşüyorlardı.

\footnotetext{
${ }^{49}$ Hürriyet, 31.10.1956.

${ }^{50}$ Cumhuriyet, 06.11.1956; Cumhuriyet 07.11.1956.

${ }^{51}$ The Times, 4 December 1956.

${ }^{52} \mathrm{M}$. Copeland, Bandung Konferansında iyi bir etki yaratan Nasır, Mısır'ın bölgesel bir güç yapma peşinde olduğunu belirtmektedir. Devletler Oyunu, ss.180-183:; Ayrıca çeşitli konuşmalarında bunu dile getirmiştir. Gamal Abdel Nasser, on Africa, U.A.R. State
} Information Servise, (?) s. 4, s.8, s.9. 
Süveyş krizi İngiltere'nin bölgeden çekilirken bunun yerine $\mathrm{ABD}$ bölgeye güçlü bir şekilde girdi. ABD bölgeye girerken İngiltere'den doğan boşluğun Sovyetler Biriliği tarafından doldurulacağını ileri sürdü. Bunun bir sonucu olarak Ocak 1957'de Eisenhower doktrini ilan edildi. Bu doktrinin temeli Ortadoğu'da komünizm tehdidini önlemekti. Bunun için bölgeye $\mathrm{ABD}$ hem askeri hem de ekonomik yardım yapmayı üstlenmekteydi. Ayrıca komünist tehdidi altındaki ülkeler ABD'den yardım talep ettikleri takdirde $\mathrm{ABD}$ bu devletlerin yardımına koşacaktı. Bu durum aynı zamanda MısırSovyet yakınlaşmasına da bir tepki niteliğindeydi.

Forum dergisinde Ortadoğu ile ilgili yapılan yorumlarda İsrail'in kurulmasını hata olarak değerlendirmiştir. İsrail konusu Arap milliyetçilik hareketlerinin temeline oturtuldu ${ }^{53}$. Süveyş krizi sonrası Irak, yeni arayışlara yöneldi. Irak, Suudi Arabistan, Ürdün ve Sudan'ı içine alan bir ittifak kurmaya çalıştı. Mart 1957'de Nuri Sait Paşa Nasır'ın gücünün azaldığını ve tekrar Bağdat paktını harekete geçirerek Irak'ın konumunu kuvvetlendirmeyi düşündü. Diğer yandan Sovyetler Birliği de Mısır'la iyi ilişkiler kurarak Mısır'ın Arap dünyasında etkili olmasına çalışmaktaydı. Süveyş krizinde askeri bir hezimete uğrayan Nasır bunu politik bir zafere dönüştürmeyi başarmıştı. Ancak bu mağlubiyet Mısır'ın Arap dünyasında prestij kaybetmesine neden oldu.

Irak ve Türkiye bölgedeki gelişmelerden rahatsızdı. Amerikalılarla yapılan görüşmelerde Irak hükümetine cesaretli kişilerin alınması gerektiği görüşünde birleştiler. İstanbul'da yapılan toplantıya Fatin Rüştü Zorlu katıldı. Temel amaç ise Suriye'deki rejimi değiştirmekti ${ }^{54}$. Irak, Suudi Arabistan'1 Suriye konusunda yanına çekmek istedi. Suudi Arabistan Suriye'ye karşı silah kullanılmasına karşı idi. Rejim değişikliğinin başka metodlar kullanılarak yapılmasından yanaydı. Ayrıca bölgedeki sorunlardan Nasır'1 suçlu gördüler. Irak, Ürdün'ün desteği ile Suriye'ye girmeye hazırd1 ${ }^{55}$.

İngiltere'nin Süveyş'ten çıkması Mısır'ın Batı'dan bağımsız olmasının bir göstergesi oldu. Diğer yandan Arap liderliği için Nuri Sait Paşa ile rekabete girmesi ABD tarafından iyi anlaşılmadı. Bu durum ABD'nin Ortadoğu ile ilgili planlarına olumsuz yansıd1 ${ }^{56}$. ABD'nin bölgeye girmesi

${ }^{53}$ Türkiye'nin burada nasıl bir politika izlemesi gerektiği konusunda dergi bir öneri getirmedi. Genelde hükümet ile aynı çizgiyi savunsa da uygulamalara karşı idi. Forum Dergisi, C.VI, S.65, 7 Ocak 1957.

${ }_{54}$ Declassified, tlegram from İstanbul to Secretary of State, 3 September 1957, E.O. 12958. Sec.3.6. (b) MR.99-66-1; Bu görüşmelere Irak veliahtı katıldı. Veliaht katıldığı için Irak başbakanına bu yönde bir emir vermesi çok zordu. Ancak bu amaç için orduyu harekete geçireçeğinden emindi.

55 Declassified, tlegram from İstanbul to Secretary of State, 3 September 1957, E.O. 12958. Sec.3.6. (b) MR.99-66-1; Amerikalılara göre Menderes, Suriye'ye Arapların problemi olarak baktı. Eğer burada komünist bir yönetim kurulduğu takdirde bu Türkiye'nin güvenliği için bir tehdit olurdu. Eğer Aralar müdahale etmezse Türkiye ABD ile birlikte Suriye'ye müdahale edebilirdi.

${ }^{56}$ Amos Perlmutter "The Fiasco of Anglo-American Middle East Policy", People and Politics in the Middle East, ed:Michael Curtis, New Jersey, 1971, ss.241-242. 
Arap dünyasında bölünmeye neden oldu. Bir tarafta $\mathrm{ABD}$ yardımını kabul etmeyen Suriye-Mısır, diğer tarafta komünist bir tehditten korkan ve Batıyla ekonomik bağları olan devletlerdi. Bu durumu görüşmek üzere Şubat 1957 yılında Suudi Arabistan kralı İbni Suud Washington'da Irak veliahdı ile buluştu. $\mathrm{Bu}$ buluşma iki rakip devlet arasında işbirliğine gidileceğinin bir göstergesiydi. Burada Suudi Arabistan ile Irak arasındaki ilişkilerin geliştirilmesi ve bu devletin Bağdat paktına daha olumlu yaklaşması Suudilerden istendi ${ }^{57}$. Suudi Arabistan Eisenhower doktrinine olumlu yaklaşarak Dahran üssünün kullanım süresini uzattı. Bu aynı zamanda Suudi Arabistan'ın Mısır'dan uzaklaştığının da bir ifadesiydi.

Bu gelişmelerden Ürdün'de etkilenerek Suudi Arabistan ile ilişkilerini geliştirmek istedi. Ürdün Haşimi soyundandı ve Suudi Arabistan'a hep mesafeli durmaktaydı. 1957 Şubatındaki Kahire konferansında Nasır ve Kuvvetli Eisenhower doktrinine muhalefet ederken, Suud ve Hüseyin, bu doktrinin yanında yer aldı. Bununla birlikte Ürdün, Irak-Suudi Arabistan koalisyonunda yer almaktan çekindi. Ürdün kendi ülkesindeki milliyetçi tepkilerden çekinerek daha 1 lımlı bir politika izlemekteydi. Ürdün'de milliyetçi kesimin temsilcisi Süleyman Nablisi de önemli bir faktördü. Kral ve hükümet arasındaki görüş ayrılığı Nisan 1957'de bir toplantıyla aşılmaya çalışıldı. Hüseyin, Suudi Arabistan, Irak ve ABD tarafından desteklendiği için Nablusi çekilmek zorunda kaldı. Böylelikle Ürdün'ün Mısır ve Suriye'ye yakınlaşması önlenmiş oldu.

Mayıs 1957 yılında Suudi Arabistan Kralı Bağdat'ı ziyaret ederek iki ülke arasındaki ilișkilerin daha da geliştirilmesi için görüşmeler yapıldı. Arap basını buna büyük önem vererek Irak'ın Bağdat Paktından çekilebileceğini ve yeni bir Arap paktı kurulabileceğini yazdılar. Bu yeni ittifak Suudi Arabistan, Irak, Ürdün ve Lübnan'1 kapsayacaktı. Suud'un bu ziyaretinde Mısır konusu gündeme gelmedi. Suud, Nasır'a ekonomik yardım yaptığı halde bunun karşılığını alamadığını ve Nasır'ın kendisine düşmanca bir tutum takındığından şikayet etti. Nuri Sait Paşa, Suud'un Nasır'a ekonomik yardım yapmasına karşı çıktı. Nasır ne kadar zor durumda kalırsa kendileri için o kadar iyi demekti. Türkiye Süveyş krizinde imajı sarsılan Bağdat Paktına ABD'nin katılması ile Arap dünyasında daha olumlu bir hava eseceğine inanmaktaydı. 1 Haziran 1957'de Başbakan Menderes, Bağdat Paktı toplantısı için Pakistan'a giderken bunu gerçekleştirmeyi düşündü. Ancak öneri ABD tarafından kabul edilmedi.

Suudi Arabistan, Arap dünyasında Nasır'ın da katılabileceği bir pakt kurma düşüncesinde idi. Ancak Nasır'ın buna yanaşması oldukça zordu. Diğer taraftan Irak'ta Mısır'la aynı blokta olmaya sıcak bakmayabilirdi. Suudi Arabistan ayrıca Bağdat paktının Birleşmiş Milletler yasasına göre uyum içinde olduğunu belirterek bir anlamda pakta olumlu yaklaştı. Ancak Suudi Arabistan ülkesinin pakta katılmaya niyeti olmadığını da açıklamaktan

${ }^{57}$ Elie Podeh, "The Struggle over Arap Hegemony After the Suez Crisis", Middle Eastern Studies, Vol.29, No.1, s.102. 
geri kalmadı. Ama paktın amaçlarını anladı̆̆ını belirtti. Bunun yanında İslam ülkelerinin komünizme karşı bir konferans düzenleyerek işbirliğine gitmeleri gerektiğini ümit ettiğini belirtti. Burada asıl amaç Nasır'ın Arap dünyasında yaptı̆̆ı propagandalarını önlemeye yönelikti. Türkiye'de Nasır'a yaklaşmayı denedi ${ }^{58}$. Türkiye, Arap ülkeleri arasındaki kavganın anlaşmazlığın bitmesini beklerken Ortadoğu'da var olan gerçekleri tam olarak göremedi. Türkiye'nin iyi niyetli davranışları bütün problemleri çözecek gibi algılandı.

Nasır'a karşı bir blok kurma girişimi Lübnan, Sudan, Fas, Tunus ve Libya'dan olumlu yanıt gelirken Suriye ve Misır iyice yalnızlığa itildi. 1957 Haziran'ında Suud, Amman'a, Kral Hüseyin'de Bağdat'a giderken bu Arap dünyasında yeni bir arayışın başlangıcını sembolize etmekteydi. Böylece Irak, 1957 yılından itibaren Arap dünyasında kaybettiği yeri tekrar kazanmaya başladı. Nuri Sait Paşa başta olmak üzere Irak karalı da kendisini gülcü hissetmeye başladı ${ }^{59}$. Nasır, Arap kamuoyunda prestij kazanmasına rağmen Mısır etkili konumunu kaybetmişti. Batının tam destek verdiği Irak Arap dünyasında kuvvetli bir konuma gelmişti. Oysa Nasır her şeye rağmen emperyalizme kafa tutarak Arap halkının gözünde milli bir kahraman haline gelmesi göz ardı edilmekteydi.

ABD Sovyetler Birliğinin Mısır ve Suriye'ye girerek Ortadoğu'da üstün bir konuma gelmesinden çekinmekteydi. Buna neden olarak İngiltere ve Fransa'nın bölgeye karşı uyguladıkları hatalı politikalar olmuştu ${ }^{60}$. Gerçekte Arap dünyasında Nasır'a karşı bir blok oluşturmak önemliydi. Ancak bu yeni oluşan ittifak homojen bir yapıda değildi. Irak ve Türkiye Nasırı'ın gücünü kırmak için Suriye'deki rejimin değişmesinden yanaydı. Buradaki rejimin değişmesi için Irak hükümetinin kararlı tutum alması gerekmekteydi. Ürdün, Irak kuvvetlerine topraklarından geçiş izni vereceği açıktı. Türkiye ise kuvvetlerini Suriye sınırına yığarak ciddi olduğunu gösterdi. Ancak Suriye'ye karşı harekete geçmesi için daha ciddi nedenlerin olması gerektíi ${ }^{61}$. Suudi Arabistan, çıkarları tam uyuşmasa da farklı beklentiler içinde olduğundan bu ittifaka sıcak bakmaktaydı. Arap dünyasındaki gelişmeleri bildiğinden Mısır'a karşı alınacak tedbirlere katılmak istemiyordu. Böylelikle kendisini riske atmaktan geri durarak, Arap sorunlarına karışmaktan uzak bir bakıma herkese eşit durarak bir politika izlemeye çalışmaktaydı. Eylül 1957'de Beyrut'tan sonra Şam'ı ziyaret ederek Suriye ile ilişkileri normalleştirmek için adım atmaktan çekinmedi. Suudi Arabistan Mısır ve Suriye ile ters düşmesine rağmen bu devletleri karşısına almak istememekteydi.

${ }^{58}$ Başbakan Menderes, Misır'ın milli bayramı nedeniyle Ankara'da Seferathane'de verilen resepsiyona katıldı. Nasır, bir bakıma komünistlerin kuklası olarak görülmekten de vazgeçilmiş oldu. Akis, 29 Haziran 1957.

${ }^{39}$ Elie Podeh, "The Struggle over Arap Hegemony After the Suez Crisis", s.103.

${ }^{60}$ Foreign Relations of United States,1955-1957, Vol.XXVI, s.233.

${ }^{61}$ Declassified, 5 September 1957, E.O. 12950.Sec. 3.6 (b), MR 99-67-2. 
Türk basını bölgedeki gelişmeleri oldukça yanlış değerlendirdi. Hükümete muhalif yazarlar dış politikayı eleştirirken öne sürdükleri gerekçeler mevcut şartlarla bağdaşmıyordu ${ }^{62}$. Muhalefetteki Cumhuriyet Halk Partisi'de Bağdat paktı'nın başarısızlığını ABD'nin bu pakta katılmamasına bağladı ${ }^{63} .1957$ ortalarında Nasır'ın durumu tamamen değiști. Süveyş krizinin etkileri hala hissedilirken ekonomik ve siyasi anlamda Mısır'ın yalnızlı̆̆ı doruk noktaya çıktı. 23 Temmuz 1957'de Kahire'de Mısır devriminin yıldönümü kutlamalarında Arap ülkeleri askeri geçiş törenlerinde Arap devletlerinin temsilcilerinin olmaması önemli bir örnekti. Nasır yalnızlı̆̆a itilince kitleler üzerindeki etkisini de giderek azalacaktı. Bu kaçınılmaz bir gelişmeydi. Bu nedenle Nasır, bu durumu anlayarak politik yalnızlığını kırmak için çeşitli girişimlerde bulundu. Nasır, Arap liderliğine oynamak için Arapların Müslümanların desteğini kazanması gerekti.

1957 yılını bir bakıma soğuk savaşın hız kazandığı ve Suriye üzerinde üstünlüğü ele geçirmek için büyük bir rekabete sahne oluyordu. 12 Ağustosta Suriye 3 ABD'li diplomatı Suriye'deki rejimi devirmek istemekle suçlayarak sınır dışı etti. ABD, bu ülkeye Sovyetlerin yerleşmesinden korkarken aynı kaygıları Türkiye ve Irak'ta taşımaktaydı. Burada komünist bir rejimin kurulması Ortadoğu'daki dengeleri değiștirebilirdi. Suriye arkasına Sovyet desteğini aldığından sınır ihlallerine girişebilirdi. Irak, Lübnan ve Ürdün'e karşı Suriye'nin bir tecavüzü olduğu takdirde Irak harekete geçebilecekti. Durum fazla gerginleşmediği için Türkiye askeri hazırlıklara girişmedi. Ancak olabilecek bir Irak-Suriye savaşında Irak askerleri yetersiz kaldığı takdirde Türkiye'de Irak'ın yanında yer alabilirdi. Kıbrıs sorunu ile Yunanistan ile Türkiye'nin ilişkileri iyi değildi. Yunanistan, Türkiye'ye karşı diplomatik harekete geçerek ülkesinde yapılan askeri manevralara Suriyeli askeri yetkilileri davet etti ${ }^{64}$. Diğer taraftan Türkiye, Suriye'ye karşı tek başına harekete geçtiğinde Arap dünyasından bir destek bulması zordu. Bu durum Pan-arapizm komünist propaganda ile desteklenerek yoğun bir Batı karşıtlığı oluşabilirdi ${ }^{65}$. Macaristan'dan Sovyet askerlerinin çıkmaması bu devlete duyulan kuşkuları artırdı. Sovyetlerin Birleşmiş Milletler kararlarına uymaması nedeniyle $\mathrm{ABD}$ daha aktif bir politika izlemeye başlayarak kendisi inisiyatif kullanmaya karar verdi. ABD'nin ortadoğu'ya girmesi uluslararası rekabetin artmasına neden oldu ${ }^{66}$. Burada Suriye merkezli bir üstünlük mücadelesine sahne olmaktaydı. Nasır, bu rekabetti kaybettiği anda Arap dünyasındaki etkinliğini de yitirecekti. O

${ }^{62}$ Metin, Toker, "Mutabık Kaldığımız Politika, Akis, 9 Şubat 1957; M. Toker, Arapların Türkiye'ye olumsuz davranışlarını hükümetin beceriksiz politikasına bağlarken bunun Türkiye'nin çelişsili politikasına dayandırdı.

${ }^{63}$ Akis, 9 Mart 1957. 385-7.

${ }^{64}$ White House, Staff Notes No.186, Secret, 4 September 1957, Declassified, MR 86-

${ }^{65}$ State Dept. Secret 5 December 1957 E.O. 12950. sec 3.6 (b), MR 99-67. doc.2.

66 Türkiye ABD'nin bölgeye girmesini ve burada bir şeyler yapılması konusunda ısrarlıydı. Ortadoğu'daki kanserin sökülüp atılması gerekliydi. Aksi taktirde gelișen olaylar Türkiye'yi etkilemesi kaçınılmazdı. Ancak ABD askeri harekat düşünmedi. Memorandum of Conference with the President, 7 December 1957, E.O. 12958. sec.3.6. (b) E.O. 97-00544. 
nedenle Suriye Mısır için son derece önemliydi. Ayrıca bu Nasır'ın Arap liderliğine de indirilecek büyük bir darbeydi. Bu nedenle Suriye'de kontrolü ele geçirerek bölgesel liderliği ele geçirebilir ve diğer Arap devletlerinin Irak'ın yanında yer almasını önleyebilirdi. 1955 yılında imzalanan Mısır ile Suriye arasındaki ittifak maddelerine dayanarak Latakiyya'ya 13 Ekim'de Mısır askerleri girdi. Böylelikle Nasır Suriye problemini çözen lider konumuna geldi. Bu durum Suriye'nin Misır etkisinde olduğunun bir göstergesiydi.

Arkasından Suriye'deki Baascıların da etkisiyle 1958 yılında Birleșik Arap Cumhuriyeti kurulması ile birlikte Arap dünyasında dengeler değişti. 1955 'ten bu yana Mısır ve Suriye birleşmeyi görüşmelerine rağmen bir türlü gerçekleşmemişti. Suriye, Mısır'ın yanında bağımsızlığını korumaktan yanaydı. Suriye'deki bürokratlar ve Baas partisi Nasır ile birleşmekten yanaydı. Ancak bu birleşme çok kolay görünürken uygulamada pek çok problemi ortaya çıkardı. Suriye'de Mısırlı bürokratlar kilit yerlere yerleştirilince bu Suriyelilerin tepkisine neden oldu. Bir bakıma Suriye, Mısır kontrolüne giren bir uydu devlet görüntüsü sergilerken Suriyeliler bundan rahatsızlık duymaya başladı.

Mısır'ın Suriye'deki askeri başarısı Mısır'ın Arap dünyasındaki yalnızlığını giderdi. Bununla güçlenen Nasır, Bağdat paktına ve Eisenhower doktrinine daha sert bir tavır aldı. Ocak 1958 yılında Bağdat Paktının yıllık toplantısı Ankara'da yapıldı. Buna ABD Dışişleri Bakanı Dulles'te katıldı. Nasır, Bağdat Paktının NATO'ya bağlanacağı endişesini taşımasıyla Mısır basını Bağdat Paktına karşı sert bir kampanya başlattı. Burada Bağdat Paktının her toplantısında Arap dünyası aleyhine bir karar çıktığı yazıldı. Ayrıca Suriye-Mısır birleşmesine Bağdat Paktının karşı olduğu da vurgulandı. Nasır, kendisini fazla güvende hissetmediği için Suriye ile birleşmesi bir bakıma bu korkuların azalmasıydı. Bu durumda Birleşik Arap Cumhuriyeti yalnızca Suriye için bir kalkan değil aynı zamanda Mısır içinde geçerliydi.

Bu birleşme Mısır'ın bölgedeki etkinliğinin artmasına neden oldu. Birleşik Arap Cumhuriyetinin bir askeri eylem sonucu yaratılması, Nasır'ın Arap dünyası üzerindeki öncü rolünü de pekiştirdi. Suriye kendi politik yapısı içinde büyük güçlerin rekabetine açık bir saha görünümünü verdi. Mısır, bu birleşme ile yalnızca kendi konumunu güçlendirirken Suriye için aynı şeyleri söylemek mümkün değildi. Nasır, Suriye'ye hâkim olarak Ürdün ve Irak'taki rejime karşı kuvvetli bir pozisyon elde etti. Aslında bu birleşme Nasır'ın temelde amaçladığı bir şey olmasa da kendi çıkarlarına son derece uygun düşmüştü.

Birleşik Arap Cumhuriyetinin yaratılması Nasır'ın taktik bir başarısıydı. Arap dünyasında Mısır'ın yalnızlığını kırarken diğer yandan Nasır'ın liderlik konumunu sağlamlaştırdı. Süveyş krizi arkasından Suriye ile birleşmesi Arapların gözünde Nasır uzun süre aradıkları bir kahraman statüsüne geldi. Buna karşı Ürdün ile Irak'ın Arap Birliği yaratma çabaları 14 Şubatta 
başarısızlığa uğradı. Arkasından çok geçmeden 14 Temmuz 1958 yılında Irak'ta bir darbe olmasıyla bu ülkedeki Haşimilerin egemenliği sona erdi ${ }^{67}$. Mayıs 1958 yılında Lübnan'da sivil savaş başlarken Nasırcılar burada da etkiliydi. Böylelikle 1958 yılında Nasır gücünün zirvesine ulaşırken Irak farklı bir döneme girerek Arap dünyasındaki pozisyonunu yitirdi. Nasır, pan Arabizmin tartışmasız liderli konumuna yükselirken siyasal alandaki büyük şansı kendisini bu konuma yükseltti. Bir bakıma onun kişisel yetenekleri öngörüyle değil o anki koşullar kendisine bunu sağladı. 1967'deki Haziran savaşında büyük yenilgi alması bile imajını sarsmadı ${ }^{68}$.

\section{Sonuç}

Türkiye, Demokrat Parti iktidarı ile birlikte daha aktif bir dış politika izlemeye başladı. Sovyetlerin Ortadoğu'ya inmesini önlemek için bölgesel bir pakt kurmayı amaçladı. Türkiye, Mısır'ın İngiltere ile anlaşmasına güvenerek Bağdat Paktına diğer Arap devletlerinin de gireceğini ümit etti. Ancak bu pakt özellikle Nasır'ın şiddetli tepkisi ile karşılaştı. Nasır'a göre batı yardımını alacak olan Irak, Arap liderliğine oynayabilirdi. Nasır bunu önlemek için Suriye'ye yaklaşırtı. Türkiye ise paktın kurulduğu andan itibaren işler beklediği gibi gitmedi. Mısır, Suriye 'nin yanında İsrail'de bu pakta karşı çıkarken Türkiye'ye tepkiler arttı. Süveyş krizi, Suriye'nin Sovyetler'den yardım alması Arap dünyasında batı düşmanlığını yaygınlaştırdı. Türkiye, Sovyetler Birliği'ne karșı güvenliğini sağlamak için batıya yanaşırken, Arap dünyası, İsrail'in kurulmasından batıyı sorumlu tutmaktaydı. Türkiye böyle bir ortamda Arap ülkelerine yaklaşması buradaki görüş ayrılıklarını artırdı. Süveyş krizinde Mısır'a destek vermeyen Türkiye, Nasır'ın devrilmesini bekledi. Bu gerçekleşmeyince de Mısır ile ilişkileri yumuşatma yoluna giderken Suriye'nin Sovyet etkisine girmesi Türkiye'yi kaygılandırdı. Türkiye ciddi olarak bu ülkeye karşı bir silahlı müdahale de bulunmak istediyse de ABD'nin destek vermemesi üzerine kriz daha da büyümeden sona erdi. Türk basını ise Ortadoğu'daki Türk hükümetinin politikasını eleştirirken onlarda bölgedeki gelişmeleri anlamaktan uzaktı.

${ }^{67}$ İlk gelen bilgiler darbenin Nasır yanlılarınca yapıldığı yönündeydi. Briefing notes, 14 July 1958, E.O. $12065 \mathrm{sec} .1-301$ (d) MR. 78-204 d.2.

${ }^{68}$ Leland Bowie, "Charisma, Weber and Nasir" Middle East Journal, Spring 1976, Vol.30. No.2,s.151. 